\title{
nature
}

\section{Europe needs to pull its weight in research}

A broader vision of a pan-European research enterprise will remain just that until the continent's nation states become more imaginative in their approaches to collaboration.

A fter years of discussion, the fragmented nature of Europe's research base continues to jar against the lofty rhetoric about a united Europe. The European Science Foundation, an association of Europe's national research agencies founded in 1974, remains a bit-player on the continent's research scene. And the European Research Area (ERA), conceived in 1999, still means more in diplomatic circles than in scientific ones (see News Feature, page 768).

Yet the total research investments of the United States and Japan continue to far outstrip those of any European nation, and the need for Europe to pool its limited resources has never been greater. It is time for European scientists to take a hard look at the existing mechanisms for collaboration, and to ask if they are delivering.

Supporters of the ERA, which is intended to unite European science, say it is already approaching reality. The European Commission's Framework programmes for research, large research projects such as CERN, the particle physics laboratory near Geneva, innumerable bi- and multilateral projects, and platforms such as Euroforum, a group of leading European research organizations, have, they argue, already transformed the continent's scientific landscape.

Sceptics take issue with this rosy picture. They point out that $95 \%$ of science in Europe is still funded and conducted in single nation states. Governments and funding agencies jealously supervise their spheres of influence and the interests of their specific clientèle. And the structure of research and of scientists' careers in, say, Spain, Slovenia, Finland and Britain are utterly distinct from one another.

Furthermore, the incentives for mobility and scientific exchange within Europe remain weak. There are, for instance, more active French scientists in the Boston area than in the entire European
Union (EU) outside France. Meanwhile, in terms of research spending, patents and high-technology exports per capita, the United States and Japan each continue to lead the EU.

A more productive research and education system is therefore needed, and it is in this light that EU leaders have backed the concept of the ERA. But it cannot be imposed by decree; it needs the combined political will and creativity of all the EU member states.

If Europe is serious about improving its science base, it should start by building on existing strengths. Multinational laboratories, such as CERN and the European Synchrotron Radiation Facility in Grenoble, boast some of the world's best scientists. And there is ample potential for Europe to lead in other areas - climate-change research and cell biology are just two examples. Five or six major new facilities, with a strong capacity to train and integrate scientists from countries spending too little on science, would give European science a valuable boost.

The EU must also decide about a central funding agency for Europe, of the type advocated by the European Science Foundation. There are good reasons for creating such an agency, but its design and goals must be carefully defined. It might find a niche, for example, by concentrating on supporting high-risk projects in basic research that are failing to win support under the current system.

In the United States, DARPA, the Defense Advanced Research Projects Agency, has found such a niche, supporting important basic research in various disciplines. It achieves this by seconding outstanding individuals from the universities as its programme managers, and allowing them more leeway in project selection than other research agencies. To progress, European research needs support mechanisms involving less red tape and a greater willingness to tolerate failure.

\section{A Goldin legacy}

The US space programme will miss the colour, character and energy that NASA's departing administrator brought to his job.

W hatever else might be said about Dan Goldin, who resigned last week as administrator of the US space agency NASA, he was never dull. In every situation, Goldin displayed an occasionally reckless passion that made him one of the most inspiring leaders the agency has had.

Goldin's legacy will doubtless be closely tied to the aphorism, "better, faster, cheaper", which he applied to the agency's missions. For space scientists, the 'faster' element was particularly welcome. Goldin managed to increase the flight rate of small spacecraft, and so rescued space science from the tedium and inherent risk of flying one giant mission every five or ten years.

The verdict is still out on 'better' and 'cheaper', however. NASA engineers of the old school used to say, "better, faster, cheaper — pick any two". After more than nine years under Goldin, their scepticism may yet win out. They can, after all, point to NASA's Mars programme, which became cheaper and faster but lost two spacecraft in the process.

The International Space Station was, of necessity, Goldin's other preoccupation. His supporters will say that he got the project built in difficult circumstances. Construction, so far, has gone remarkably smoothly. But the budget is again out of control, placing the project back in crisis mode - just where it was when Goldin arrived in 1992.

Even if his vision of a streamlined NASA does fall flat, not all of the blame should fall on Goldin. He was a reformer with little real power to reform. Unlike a corporate executive, he couldn't shape his organization as he wished - not with congressional delegations protecting every NASA field centre. So official Washington cheered him on, but never really got behind his efforts to reform the space agency. That was unfortunate for NASA: men such as Goldin don't arrive in government administration very often, and it will be lucky to see his like again. 